\title{
PENGARUH PERSEPSI GURU MENGENAI KEPEMIMPINAN KEPALA SEKOLAH TERHADAP KINERJA PEDAGOGIK GURU DI SD NEGERI 2 KENDARI
}

\author{
Agus Renal $^{1)}$, Izlan Sentryo ${ }^{1)}$, Rimba Hamid ${ }^{1)}$ \\ 1) Jurusan Pendidikan Guru Sekolah Dasar \\ FKIP Universitas Halu Oleo \\ Email: agusrenala1g116070@gmail.com, izlan.sentryo@gmail.com, \\ rimbahamid@uho.ac.id
}

\begin{abstract}
Abstrak: Penelitian ini bertujuan untuk mengetahui pengaruh persepsi guru mengenai kepemimpinan kepala sekolah terhadap kinerja pedagogik guru di SD Negeri 2 Kendari. Penelitian ini dilatar belakangi oleh masih terdapat guru yang mengajar di kelas berdasarkan pengalaman masa lalunya dari waktu kewaktu sehingga merasa menguasai materi di luar kepala dan tidak mau mengubahnya kepada hal-hal yang baru termasuk metode pembelajaran, penggunaan media, sistem penilaian yang kurang dipahami dan mengajar secara hafalan atau tanpa persiapan mengajar sebelumnya. Sementara itu kepemimpinan kepala sekolah belum dapat sepenuhnya mempengaruhi, menggerakkan, mengembangkan dan memberdayakan guru untuk dapat meningkatkan motivasi kerja dan kinerja tersebut. Penelitian ini adalah penelitian kuantitatif dengan pendekatan expost facto. Sampel dalam penelitian ini adalah seluruh guru SD Negeri 2 Kendari yang berjumlah 31 orang. Instrumen pengumpulan data berupa kuesioner dengan skala likert yang memiliki 4 alternatif jawaban, terdiri atas 40 butir. Instrumen penelitian diujicobakan kepada 14 guru di SDN 100 Kendari. Hasil penelitian menunjukkan bahwa (1) Kepemimpinan Kepala sekolah di SDN 2 Kendari menurut sebagian besar guru (94\%) termasuk dalam kategori tinggi; kemudian (2) Kinerja pedagogik guru SDN 2 Kendari lebih dari separuh guru (74\%) dalam kategori tinggi; dan (3) Terdapat pengaruh positif dan signifikan antara kepemimpinan kepala sekolah berdasarkan persepsi guru terhadap kinerja pedagogik guru sebesar $29,27 \%$ sedangkan 70,83\% lainnya dijelaskan oleh variabel lain yang tidak termasuk dalam penelitian ini.
\end{abstract}

Kata kunci: Kepemimpinan Kepala Sekolah; Kinerja Pedagogik Guru

\section{THE EFFECT OF TEACHERS 'PERCEPTIONS OF SCHOOL LEADERSHIP ON TEACHER'S PEDAGOGIC PERFORMANCE IN SD NEGERI 2 KENDARI}

\begin{abstract}
This research aims to determine the effect of teacher perceptions of principal leadership on teacher pedagogical performance at SD Negeri 2 Kendari. This research is motivated by there are still teachers who teach in the classroom based on their past experiences from time to time so they feel they have mastered the material by rote and do not want to change it to new things including learning methods, use of media, poorly understood assessment systems and teaching. by rote or without prior teaching preparation. Meanwhile, the principal leadership has not been able to fully influence, mobilize, develop and empower teachers to be able to increase work motivation and performance. This research is a quantitative research with an ex post facto approach. The sample in this research were all teachers of SD Negeri 2 Kendari, amounting to 31 people. The data collection instrument was a questionnaire with a Likert scale which has 4 alternative answers, consisting of 40 items. The research instrument was tested on 14 teachers at SDN 100 Kendari. The results showed that (1) the leadership of the principal at SDN 2 Kendari according to most teachers (94\%) was in the high category; then (2) the pedagogical performance of SDN 2 Kendari teachers is more than half of the teachers (74\%) in the high category; and (3) There is a positive and significant influence between principal leadership based on teacher perceptions of teacher pedagogical performance of $29.27 \%$ while the other $70.83 \%$ are explained by other variables not included in this research.
\end{abstract}




\section{Pendahuluan}

Pendidikan di Indonesia bertujuan untuk mengembangkan peserta didik agar menjadi manusia yang beriman dan bertakwa kepada Tuhan Yang Maha Esa, serta berahklak mulia, sehat, berilmu, cakap, kreatif, mandiri, dan menjadi warga negara yang demokratis serta bertanggung jawab (Undang-Undang Nomor 20 Tahun 2003 Bab II Pasal 3). Dalam rangka mencapai tujuan pendidikan tersebut, sekolah sebagai sarana pencapaiannya harus berhasil dalam menciptakan mutu pendidikan. Keberhasilan pendidikan di sekolah sangat ditentukan oleh keberhasilan kepala sekolah dalam mengelola tenaga kependidikan yang tersedia di sekolah. Kepala sekolah sebagai pimpinan tertinggi yang sangat berpengaruh dan menentukan kemajuan sekolah harus memiliki kemampuan administrasi, memiliki komitmen tinggi, dan luwes dalam melaksanakan tugasnya. Kepemimpinan kepala sekolah yang baik harus dapat mengupayakan peningkatan kinerja guru melalui program pembinaan kemampuan tenaga kependidikan. Oleh karena itu kepala sekolah harus mempunyai kepribadian atau sifat-sifat dan kemampuan serta keterampilanketerampilan untuk memimpin sebuah lembaga pendidikan. Dalam perannya sebagai seorang pemimpin, kepala sekolah harus dapat memperhatikan kebutuhan dan kemampuan yang dimiliki oleh guru dan berusaha untuk meningkatkan kemampuan dan kinerja guru.

Menurut Prajudi Atmosudirjo dalam Satriadi (2016, p. 124) kepemimpinan adalah sekumpulan dari serangkaian kemampuan dan sifat-sifat kepribadian termasuk didalamnya kewibawaan, untuk dijadikan sebagai sarana dalam rangka meyakinkan yang dipimpinnya agar mereka mau dan dapat melaksanakan tugas-tugas yang dibebankan kepadanya dengan rela, penuh semangat, dan kegembiraan batin serta merasa tidak terpaksa.

Menurut Crainer dalam Yudiaatmaja (2013, p. 36) ada lebih dari 400 definisi tentang leadership. Dari sekian banyaknya definisi tentang kepemimpinan, ada yang menyebutkan kepemimpinan merupakan suatu kegiatan untuk memengaruhi orang lain. Kepemimpinan merupakan suaru proses untuk memengaruhi aktivitas kelompok. Kepemimpinan merupakan kemampuan memeroleh kesepakatan pada tujuan bersama. Kepemimpinan adalah suatu upaya untuk mengarahkan orang lain untuk mencapai tujuan tertentu.

Kinerja Guru adalah kemampuan dan usaha guru untuk melaksanakan tugas pembelajaran sebaik-baiknya dalam perencanaan program pengajaran, pelaksanaan kegiatan pembelajaran dan evaluasi hasil pembelajaran. Kinerja guru yang dicapai harus berdasarkan standar kemampuan profesional selama melaksanakan kewajiban sebagai guru di sekolah (Rachmawati, 2013, p. 21). Oleh karena itu, guru yang merupakan salah satu unsur di bidang kependidikan harus berperan secara aktif dan menempatkan kedudukannya sebagai tenaga profesional, sesuai dengan tuntutan masyarakat yang semakin berkembang. Dalam hal ini guru tidak semata-mata sebagai pengajar yang melakukan transfer ilmu pengetahuan, tetapi juga sebagai pendidik yang melakukan transfer nilai-nilai sekaligus sebagai pembimbing yang memberikan pengarahan dan menuntun siswa dalam belajar.

Kinerja guru merupakan hasil kerja dan kemajuan yang dicapai oleh guru dalam melaksanakan tugas dan kewajibanya. Kinerja yang baik itu diantaranya terlihat dari guru yang ingin hadir ke sekolah dan rajin dalam mengajar, guru mengajar dengan sungguhsungguh menggunakan rencana pelajaran, guru mengajar dengan semangat dan senang hati, menggunakan metode yang bervariasi sesuai dengan materi pelajaran, melakukan evaluasi pengajaran dan menindak lanjuti hasil evaluasi. Kinerja guru yang tinggi ini akan banyak memberikan pengaruh yang kuat terhadap keberhasilan peserta didik dalam mencapai tingkat kompetensinya. Namun demikian, kinerja guru juga disangkutpautkan dengan kepemimpinan kepala sekolah, komunikasi antar sesama guru dan kepala sekolah 
dapat dikatakan kurang berjalan dengan baik, kepala sekolah kurang memberikan motivasi yang penuh terhadap guru sehingga terkadang guru masih enggan untuk mengembangkan tingkat profesionalitasnya. Dengan kondisi seperti ini, otomatis akan terjadi pergeseran peran guru dalam proses pengembangan potensi peserta didik, yakni guru hanya sebagai pembekal informasi bagi peserta didik. Hal ini tidak terlepas dari pengaruh kepemimpinan kepala sekolah dalam menjalankan kepemimpinannya.

Terciptanya kualitas kinerja guru yang profesional di sekolah membutuhkan dukungan peran kepala sekolah yang kompeten sebagai leader dan manager Wahyudi dalam Yulia (2015, p. 589). Di satu sisi, kepala sekolah berperan sebagai pemimpin (leader) yang memiliki visi ke masa depan yang jelas dan dapat diwujudkan serta mampu mendorong proses transparansi di sekolah. Di sisi lain, kepala sekolah berperan sebagai manajer, yang memiliki strategi-strategi yang efektif dan efisien untuk mengimplementasikan berbagai kebijakan dan keputusan yang telah ditetapkan.

Dalam pelaksanaan manajemen berbasis sekolah secara efektif dan efisien, maka memerlukan kepala sekolah yang memiliki kemampuan kepemimpinan, perencanaan, dan pandangan yang luas tentang sekolah dan pendidikan. Wibawa kepala sekolah harus ditumbuhkembangkan dengan meningkatkan sikap kepedulian, semangat belajar, disiplin kerja, keteladanan dan hubungan manusiawi sebagai modal perwujudan iklim kerja yang konduktif. Keberhasilan organisasi mencapai tujuan yang telah ditetapkan akan sangat tergantung pada peran kepemimpinan. Demikian halnya kepemimpinan memegang peranan sangat sentral dalam dinamika kehidupan organisasi. Sebagai pemimpin, kepala sekolah merupakan salah satu faktor penentu yang dapat mendorong sekolah mewujudkan visi, misi, tujuan dan sasaran melalui berbagai program yang dilaksanakan secara terencana. Oleh karena itu kepala sekolah harus memiliki kemampuan manajemen dan kepemimpinan yang tangguh sehingga diharapkan dapat mengambil keputusan secara tepat, disamping memiliki sikap prakarsa yang tinggi dalam meningkatkan mutu pendidikan.

Tanpa kemampuan-kemampuan utama seperti kepemimpinan yang baik, kinerja yang baik, komunikasi yang baik, kemampuan dalam memecahkan masalah-masalah yang mungkin timbul dalam proses kegiatan belajar mengajar, kepala sekolah akan sulit dalam mensosialisasikan ide, usulan, saran, atau pikiran-pikiran yang dimilikinya kepada guru dan karyawan. Oleh karena itu, kepala sekolah yang merupakan pemimpin harus bisa menjadi contoh serta mampu mengayomi bawahan dan mampu mengendalikan fungsi kepemimpinannya. Untuk kepentingan tersebut kepala sekolah selayaknya mampu memobilitasi atau memberdayakan semua potensi dan sumber daya yang dimiliki, terkait dengan berbagai program, proses, evaluasi, pengembangan, kurikulum, pembelajaran di sekolah, pengelolaan tenaga kependidikan, sarana prasarana, pelayanan terhadap siswa, hubungan masyarakat, sampai pada penciptaan iklim sekolah yang kondusif. Semua ini akan terlaksana manakala kepala sekolah memiliki kemampuan untuk mempengaruhi semua pihak yang terlibat dalam kegiatan pendidikan di sekolah, yaitu untuk bekerja dalam mewujudkan tujuan sekolah.

Kepemimpinan kepala sekolah merupakan suatu kemampuan dan kesiapan kepala sekolah untuk mempengaruhi, membimbing, mengarahkan, dan menggerakkan staf sekolah agar dapat bekerja secara efektif dalam rangka mencapai tujuan pendidikan dan pengajaran yang telah ditetapkan, atau bisa dikatakan bantuan yang diberikan oleh kepala sekolah terhadap penetapan pencapaian tujuan pendidikan (Syamsul, 2017, p. 276). Kepemimpinan kepala sekolah yang efektif akan mempengaruhi partisipasi bawahan untuk melakukan apa yang menjadi tanggung jawabnya dengan perasaan puas dan dapat bekerja sesuai dengan konteknya, yaitu mampu memberikan visi, menciptakan gambaran besar, 
menetapkan tujuan yang jelas dan disetujui bersama, memonitor dan menganalisis prestasi, serta mampu mengembangkan prestasi para pengikutnya, yaitu dengan memberikan pengarahan dan panduan, melatih dan membimbing serta memberikan umpan balik. Oleh karena itu agar diperoleh kualitas pendidikan yang sesuai dengan tujuan yang telah ditetapkan maka guru dituntut untuk selalu memiliki kinerja yang tinggi.

Beberapa penelitian telah banyak menunjukkan bahwa kepemimpinan kepala sekolah sangat berpengaruh terhadap guru dalam melaksanakan kinerjanya. Sulaiman (2014) dalam penelitiannya membuktikan bahwa faktor yang paling dominan dalam menentukan kinerja guru adalah kepemimpinan kepala sekolah. Satriadi (2016) juga mengemukakan bahwa kepemimpinan kepala sekolah berpengaruh langsung terhadap kinerja guru. Apabila kepemimpinan kepala sekolah sudah baik maka kinerja gurupun terlihat baik.

Berdasarkan studi pendahuluan menunjukkan bahwa, masih terdapat guru yang mengajar di kelas berdasarkan pengalaman masa lalunya dari waktu kewaktu sehingga merasa menguasai materi diluar kepala dan tidak mau mengubahnya kepada hal-hal yang baru termasuk metode pembelajaran, penggunaan media, sistem penilaian yang kurang dipahami dan mengajar secara hafalan atau tanpa persiapan mengajar sebelumnya. Sementara itu kepemimpinan kepala sekolah belum dapat sepenuhnya mempengaruhi, menggerakkan, mengembangkan dan memberdayakan guru untuk dapat meningkatkan motivasi kerja dan kinerja tersebut, kepala sekolah belum rutin untuk melakukan kunjungan kelas, terbatasnya waktu untuk melakukan bimbingan dan memberi bantuan kepada guru dalam pembuatan silabus dan rencana pelaksanaan pembelajaran. Berbagai permasalahan dalam dunia pendidikan tentang mutu dan kualitas pendidikan dalam rangka peningkatan kinerja guru menjadi salah satu alasan dari peneliti untuk mengkaji tentang pengaruh kepemimpinan kepala sekolah terhadap kinerja guru di SD Negeri 2 Kendari.

\section{Metode penelitian}

Penelitian ini termasuk dalam jenis penelitian kuantitatif dengan pendekatan expost facto. Penelitian ini dilaksanakan di SD Negeri 2 Kendari yang berada di Jln. Di. Panjaitan, Lepo-Lepo, Kecamatan Baruga, Kota Kendari, Sulawesi Tenggara. Populasi dalam penelitian ini adalah seluruh SD di Kecamatan Baruga Kota Kendari yang berjumlah 9 sekolah. Sedangkan sampel dalam penelitian ini adalah seluruh guru SD Negeri 2 Kendari yang berjumlah 31 orang. Penentuan sampel dalam penelitian ini dilakukan menggunakan teknik sampling purposive yaitu teknik penentuan sampel dengan pertimbangan tertentu (Sugiyono, 2017, p. 85).

Penelitian ini menggunakan 2 jenis variabel yaitu variabel independen dan variabel dependen. Variabel dependen atau variabel terikat merupakan variabel yang dipengaruhi atau yang menjadi akibat, karena adanya variabel bebas, sedangkan variabel independen atau biasa disebut variabel bebas yaitu variabel yang mempengaruhi atau yang menjadi sebab perubahannya atau timbulnya variabel dependen. Variabel independen dalam penelitian ini adalah kepemimpinan kepala sekolah sedangkan variabel dependen adalah kinerja pedagogik guru.Teknik pengumpulan data dilakukan dengan interview (wawancara), kuesioner (angket), dan observasi (pengamatan) menggunakan instrumen berupa angket tertutup berjumlah 40 butir pernyataan yang terdiri dari 17 butir penyataan variabel kepemimpinan dan 23 butir pernyataan variabel kinerja pedagogik guru. Uji instrumen dilakukan dengan cara uji validitas menggunakan analisis korelasi Product moment dan uji reliabilitas menggunakan Cronbach's Alpha.

Teknik analisis data yang digunakan dalam penelitian ini adalah analisis statistik deskriptif dan analisis regresi sederhana. Analisis deskriptif yang dipakai dalam penelitian 
ini yaitu dengan mendiskripsikan data dengan distribusi frekuensi, pengukuran nilai sentral mean (rerata), modus, median dan simpangan baku. Sedangkan analisis regresi sederhana bertujuan untuk mengetahui pengaruh masing-masing variabel yaitu pengaruh kepemimpinan kepala sekolah (Variabel X) terhadap kinerja pedagogik guru (Variabel Y).

\section{Hasil penelitian}

\section{Analisis statistik deskriptif}

Berdasarkan hasil analisis statistik deskriptif yang diperoleh pada variabel kepemimpinan kepala sekolah dan kinerja pedagogik guru diperoleh hasil sebagai berikut.

Tabel 1. Analisis statistik deskriptif kepemimpinan kepala sekolah

\begin{tabular}{lrr}
\hline \multicolumn{1}{c}{ Deskripsi } & $\begin{array}{r}\text { Kepemimpinan } \\
\text { Kepala Sekolah }\end{array}$ & $\begin{array}{r}\text { Kinerja Pedagogik } \\
\text { Guru }\end{array}$ \\
\hline Mean & 59,65 & 78,74 \\
\hline Median & 60,00 & 79,00 \\
\hline Mode & $59^{\mathrm{a}}$ & 79 \\
\hline Std. Deviation & 3,061 & 4,858 \\
\hline Minimum & 53 & 70 \\
\hline Maximum & 68 & 92 \\
\hline Sum & 1849 & 2441
\end{tabular}

Berdasarkan tabel di atas dapat diketahui bahwa hasil skor tertinggi pada variabel kepemimpinan kepala sekolah adalah 68, sedangkan skor terendah yang diperoleh adalah 53. Nilai mean yang diperoleh adalah sebesar 59,65; standar deviation sebesar 3,061; median sebesar 60; dan modus sebesar 59. Setelah dilakukan pengkategorisasian kepemimpinan kepala sekolah berdasarkan persepsi dari guru di SDN 2 Kendari dapat diketahui bahwa sebanyak 29 orang guru atau sebesar $94 \%$ mempunyai penilaian tentang kualitas kepemimpinan kepala sekolah pada kategori tinggi. Sedangkan 2 orang guru atau sebesar 6\% menilai kualitas kepemimpinan kepala sekolah berada pada kategori sedang. Sedangkan hasil skor tertinggi pada variabel kinerja pedagogik guru adalah 92, dan skor terendah yang diperoleh adalah 70. Nilai mean yang diperoleh adalah sebesar 78,74; standar deviation sebesar 4,858; median sebesar 79; dan modus sebesar 79. Setelah dilakukan pengkategorisasian kinerja pedagogik yang dimiliki oleh guru di SDN 2 Kendari dapat diketahui bahwa sebanyak 23 orang atau sekitar $74 \%$ guru memiliki kinerja pada kategori tinggi. Sedangkan 8 orang guru atau sekitar $26 \%$ memiliki kinerja pada kategori sedang.

\section{Uji Prasyarat Analisis}

Untuk melakukan pengujian terhadap hipotesis penelitian yang diajukan maka dianalisis menggunakan teknik analisis regresi sederhana. Namun sebelum melakukan analisis regresi perlu dilakukan pengujian persyaratan analisis yang berupa uji normalitas sebaran, dan uji linearitas.

\section{a. Uji Normalitas}

Uji normalitas sebaran dilakukan untuk menguji apakah data pada masing-masing variabel penelitian terdistribusi normal atau tidak. Teknik analisis yang digunakan dalam penelitian ini adalah Kolmogorov Smirnov. Taraf signifikansi yang digunakan sebesar $\alpha=$ 
0,05 (p-value > 0,05). Hasil perhitungan uji normalitas menggunakan Kolmogorov Smirnov dengan SPSS 21.0 sebagai berikut:

Tabel 2. Hasil Uji Normalitas

One-Sample Kolmogorov-Smirnov Test

\begin{tabular}{llr}
\hline & & \multicolumn{2}{c}{$\begin{array}{c}\text { Unstandardized } \\
\text { Residual }\end{array}$} \\
\hline $\mathrm{N}$ & & 31 \\
\hline \multirow{2}{*}{ Normal Parameters ${ }^{\mathrm{a}, \mathrm{b}}$} & Mean &, 0000000 \\
\cline { 2 - 3 } & Std. Deviation & 4,08671031 \\
\hline \multirow{2}{*}{$\begin{array}{l}\text { Most Extreme } \\
\text { Differences }\end{array}$} & Absolute &, 095 \\
\cline { 2 - 3 } & Positive &, 068 \\
\cline { 2 - 3 } & Negative &,- 095 \\
\hline Kolmogorov-Smirnov Z &, 528 \\
\hline Asymp. Sig. (2-tailed) &, 943 \\
\hline a. Test distribution is Normal. & \\
b. Calculated from data. & \\
\multicolumn{2}{l}{$\begin{array}{l}\text { Sumber : data diolah } \\
\end{array}$}
\end{tabular}

Dasar pengambilan keputusan dalam uji normalitas adalah: 1) jika nilai signifikansi (Sig.) lebih besar dari 0,05 maka data penelitian berdistribusi normal, 2) sebaliknya, jika nilai signifikansi (Sig.) lebih kecil dari 0,05 maka data penelitian tidak berdistribusi normal. Berdasarkan tabel perhitungan diatas dapat diketahui bahwa nilai signifikansi Asiymp.Sig (2-tailed) sebesar 0,943. Maka sesuai dengan dasar pengambilan keputusan dalam uji normalitas kolmogorov-smirnov dapat ditarik kesimpulan bahwa data kepemimpinan kepala sekolah (X) dan kinerja guru (Y) berdistribusi normal.

\section{b. Uji Linearitas}

Uji ini dilakukan untuk mengetahui apakah variabel bebas $(\mathrm{X})$ dan variabel terikat (Y) mempunyai hubungan yang linier. Untuk mengujinya dilakukan dengan uji $\mathrm{F}$ penyimpangan data dari garis linier (deviation from linierity) yang digunakan untuk memprediksikan model. cara yaitu:

Dasar pengambilan keputusan dalam uji linearitas dapat dilakukan dengan dua

- Membandingkan nilai signifikansi (Sig.) dengan 0,05

1) Jika nilai Deviation from Linearity Sig. $>0,05$ maka terdapat hubungan yang linear secara signifikan antara variabel independent dengan variabel dependent.

2) Jika nilai Deviation from Linearity Sig. $<0,05$ maka tidak ada hubungan yang linear secara signifikan antara variabel independent dengan variabel dependent.

- Membandingkan nilai $F_{\text {hitung }}$ dengan $F_{\text {tabel }}$

1) Jika nilai $F_{\text {hitung }}<\mathrm{Ft}_{\text {abel }}$, maka terdapat hubungan yang linear secara signifikan antara variabel independent dengan variabel dependent.

2) Jika nilai $F_{\text {hitung }}>F_{\text {tabel }}$, maka tidak ada hubungan yang linear secara signifikan antara variabel independent dengan variabel dependent. 
Tabel 3. Hasil Uji Linearitas

ANOVA Table

\begin{tabular}{|c|c|c|c|c|c|c|c|}
\hline & & & $\begin{array}{c}\text { Sum of } \\
\text { Squares }\end{array}$ & $\mathrm{df}$ & $\begin{array}{c}\text { Mean } \\
\text { Square }\end{array}$ & $\mathrm{F}$ & Sig. \\
\hline \multirow{5}{*}{$\begin{array}{l}\text { Kinerja } \\
\text { Pedagogik } \\
\text { Guru * } \\
\text { Kepemimpinan } \\
\text { Kepala Sekolah }\end{array}$} & \multirow{3}{*}{$\begin{array}{l}\text { Between } \\
\text { Groups }\end{array}$} & (Combined) & 445,102 & 11 & 40,464 & 2,925 &, 019 \\
\hline & & Linearity & 206,899 & 1 & 206,899 & 14,957 &, 001 \\
\hline & & $\begin{array}{l}\text { Deviation } \\
\text { from } \\
\text { Linearity }\end{array}$ & 238,203 & 10 & 23,820 & 1,722 &, 148 \\
\hline & \multicolumn{2}{|c|}{ Within Groups } & 262,833 & 19 & 13,833 & & \\
\hline & \multicolumn{2}{|l|}{ Total } & 707,935 & 30 & & & \\
\hline
\end{tabular}

Sumber : data diolah 0

Berdasarkan hasil perhitungan dari tabel di atas diperoleh nilai signifikansi sebesar 0,148 (lebih besar dari 0,05) maka dapat disimpulkan bahwa terdapat hubungan linear antara variabel kepemimpinan kepala sekolah (X) dan kinerja pedagogik guru (Y). Kemudian dilihat berdasarkan nilai $\mathrm{F}_{\text {hitung }}$ dan $\mathrm{F}_{\text {tabel }}$, dari output di atas diperoleh nilai $F_{\text {hitung }}$ adalah 1,722 $<\mathrm{F}_{\text {tabel }} 2,38$. Karena nilai $F_{\text {hitung }}$ lebih kecil dari nilai $F_{\text {tabel }}$ maka dapat disimpulkan bahwa terdapat hubungan linear antara variabel kepemimpinan kepala sekolah (X) dengan variabel kinerja pedagogik guru (Y).

Nilai $F_{\text {tabel }}$ ditentukan menggunakan rumus (df) Deviation from Linearity ; Within Groups. Berdasarkan output di atas diketahui nilai df adalah $(10 ; 19)$. Kemudian kita tinggal melihat distribusi nilai $F_{\text {tabel }}$ pada signifikansi 0,05 dengan berpedoman pada nilai df tersebut. Maka ditemukan nilai $\mathrm{F}_{\text {tabel }}$ adalah sebesar 2,38.

\section{Pengujian Hipotesis Statistik}

Pengujian hipotesis dalam penelitian ini menggunakan analisis regresi linear sederhana. Analisis tersebut digunakan untuk mengetahui koefisien korelasi baik secara sendiri-sendiri ataupun bersama-bersama. Adapun hipotesis yang diuji adalah sebagai berikut :

$\mathrm{H}_{0}$ : Persepsi guru mengenai kepemimpinan kepala sekolah tidak berpengaruh positif terhadap kinerja pedagogik guru di SD Negeri 2 Kendari.

$\mathrm{H}_{1}$ : Persepsi guru mengenai kepemimpinan kepala sekolah berpengaruh positif terhadap kinerja pedagogik guru di SD Negeri 2 Kendari.

\section{a) Output bagian pertama}

Tabel 4. Hasil Analisis Regresi

\begin{tabular}{lllllll}
\multicolumn{8}{c}{ ANOVA $^{\text {a }}$} \\
\hline Model & $\begin{array}{c}\text { Sum of } \\
\text { Squares }\end{array}$ & Df & $\begin{array}{c}\text { Mean } \\
\text { Square }\end{array}$ & F & Sig. \\
\hline \multirow{3}{*}{1} & Regression & 206,899 & 1 & 206,899 & 11,975 &, $002^{\text {b }}$ \\
\cline { 2 - 8 } & Residual & 501,036 & 29 & 17,277 & & \\
\cline { 2 - 7 } & Total & 707,935 & 30 & & & \\
\hline
\end{tabular}

a. Dependent Variable: Kinerja Pedagogik Guru

b. Predictors: (Constant), Kepemimpinan Kepala Sekolah

Sumber : data diolah

Dasar pengambilan keputusan dalam uji regresi sederhana dapat mengacu pada dua hal, yakni membandingkan nilai Sig. dengan 0,05 (jika nilai Sig. $<0,05$ maka terdapat pengaruh variabel bebas terhadap variabel terikat, begitupula sebaliknya) dan membandingkan nilai $t_{\text {hitung }}$ dengan $t_{\text {tabel }}$ (jika nilai $t_{\text {hitung }}>t_{\text {tabel }}$ maka terdapat pengaruh 
variabel bebas terhadap variabel terikat, begitupula sebaliknya). Dari hasil output di atas diperoleh nilai Sig. sebesar 0,002 $(<0,05)$ sehingga dapat disimpulkan bahwa hipotesis $\mathrm{H}_{0}$ : persepsi guru mengenai kepemimpinan kepala sekolah tidak berpengaruh positif terhadap kinerja pedagogik guru di SD Negeri 2 Kendari (ditolak) dan hipotesis $\mathrm{H}_{1}$ : persepsi guru mengenai kepemimpinan kepala sekolah berpengaruh positif terhadap kinerja pedagogik guru di SD Negeri 2 Kendari (diterima).

\section{b) Output bagian kedua}

Uji regresi ini dilakukan dengan tujuan untuk mengetahui hubungan masingmasing variabel adalah pengaruh antara kepemimpinan kepala sekolah dengan kinerja guru menggunakan persamaan regresi.

Tabel 5. Hasil Analisis Regresi

\begin{tabular}{|c|c|c|c|c|c|c|}
\hline \multicolumn{7}{|c|}{ Coefficients $^{\mathbf{a}}$} \\
\hline \multirow{2}{*}{\multicolumn{2}{|c|}{ Model }} & \multicolumn{2}{|c|}{$\begin{array}{c}\text { Unstandardized } \\
\text { Coefficients }\end{array}$} & \multirow{2}{*}{$\begin{array}{c}\text { Standardized } \\
\text { Coefficients } \\
\text { Beta }\end{array}$} & \multirow[t]{2}{*}{$\mathrm{t}$} & \multirow[t]{2}{*}{ Sig. } \\
\hline & & $\mathrm{B}$ & Std. Error & & & \\
\hline & (Constant) & 27,571 & 14,806 & & 1,862 & 073 \\
\hline 1 & $\begin{array}{l}\text { Kepemimpinan } \\
\text { Kepala Sekolah }\end{array}$ & ,858 & ,248 & ,541 & 3,461 & ,002 \\
\hline
\end{tabular}

a. Dependent Variable: Kinerja Pedagogik Guru

Sumber : data diolah

Berdasarkan tabel di atas, kolom B pada constant (a) adalah 27,571 sedangkan nilai kepemimpinan kepala sekolah (b) adalah 0,858. Untuk memprediksi seberapa jauh perubahan variabel terikat, bila nilai variabel bebas dimanipulasi atau diubah-ubah, maka ditentukan dengan persamaan regresi.

$$
\begin{aligned}
& \mathrm{Y}=\mathrm{a}+\mathrm{bX} \\
& \mathrm{Y}=27,571+0,858 \mathrm{X}
\end{aligned}
$$

Koefisien $\mathrm{b}$ dinamakan koefisien arah regresi dan menyatakan perubahan rata-rata variabel Y untuk setiap perubahan variabel X sebesar satu satuan. Perubahan ini merupakan pertambahan bila $\mathrm{b}$ bertanda positif dan penurunan bila $\mathrm{b}$ bertanda negatif. Sehingga persamaan tersebut dapat diterjemahkan:

1) Konstanta sebesar 27,571 menyatakan bahwa jika nilai kepemimpinan kepala sekolah tidak ada (nol) maka nilai kinerja guru sebesar 27,571.

2) Koefisien regresi $X$ sebesar 0,858 menyatakan bahwa setiap penambahan 1 nilai kepemimpinan kepala sekolah, maka nilai kinerja pedagogik guru bertambah sebesar 0,858. Dengan kata lain bahwa semakin tinggi tingkat kepemimpinan kepala sekolah maka kinerja pedagogik guru akan semakin meningkat.

\section{c) Output bagian ketiga}

Tabel 7. Hasil Analisis Regresi

\begin{tabular}{lcccc}
\multicolumn{4}{c}{ Model Summary $^{\mathbf{b}}$} \\
\hline Model & R Square & $\begin{array}{c}\text { Adjusted R } \\
\text { Square }\end{array}$ & $\begin{array}{c}\text { Std. Error of } \\
\text { the Estimate }\end{array}$ \\
\hline 1 &, $541^{\text {a }}$ &, 2927 &, 268 & 4,157 \\
\hline a. Predictors: (Constant), Kepemimpinan Kepala Sekolah \\
b. Dependent Variable: Kinerja Pedagogik Guru \\
Sumber : data diolah
\end{tabular}


Tabel di atas menjelaskan besarnya nilai korelasi atau hubungan (R) yaitu sebesar 0,541 dan dijelaskan besarnya persentase pengaruh variabel bebas terhadap variabel terikat yang disebut koefisien determinasi yang merupakan hasil dari penguadratan R. Dari output tersebut diperoleh koefisien determinasi $\left(\mathrm{R}^{2}\right)$ sebesar 0,2927 yang mengandung pengertian bahwa pengaruh variabel bebas (kepemimpinan kepala sekolah) terhadap variabel terikat (kinerja Pedagogik guru) adalah sebesar $29,27 \%$ sedangkan $70,83 \%$ dipengaruhi oleh variabel lain yang tidak termasuk dalam penelitian ini.

\section{Pembahasan}

\section{Kepemimpinan Kepala Sekolah SD Negeri 2 Kendari}

Pada penelitian ini dideskripsikan kualitas kepemimpinan kepala sekolah SD Negeri 2 Kendari berdasarkan persepsi dari guru yang ada di sekolah tersebut. Kepemimpinan kepala sekolah dinilai berdasarkan aspek manajerial, perencanaan, pengawasan, serta dukungan dan sosial. Berdasarkan hasil penelitian diketahui bahwa kualitas kepemimpinan kepala sekolah SD Negeri 2 Kendari dinilai oleh sebagian besar guru berada pada kategori tinggi (94\%). Sedangkan yang lainnya menilai kualitas kepemimpinan kepala sekolah SD Negeri 2 Kendari berada pada kategori sedang (6\%).

Keberhasilan pendidikan di sekolah sangat ditentukan oleh keberhasilan kepala sekolah dalam mengelolah tenaga yang tersedia di sekolah. Kepemimpinan kepala sekolah merupakan suatu kemampuan dan kesiapan kepala sekolah untuk mempengaruhi, membimbing, mengarahkan, dan menggerakkan staf sekolah agar dapat bekerja secara efektif dalam rangka mencapai tujuan pendidikan dan pengajaran yang telah ditetapkan, atau bisa dikatakan bantuan yang diberikan oleh kepala sekolah terhadap penetapan pencapaian tujuan pendidikan (Syamsul, 2017:276). Hal ini merupakan salah satu komponen pendidikan yang berpengaruhi dalam meningkatkan kinerja pedagogik guru. Sejalan dengan itu, Yudiaatmaja (2013, p. 30) juga menjelaskan bahwa kepemimpinan adalah sebuah hubungan yang saling memengaruhi antara pemimpin dan pengikutnya.

Kepala sekolah bertanggung jawab atas pengelolaan segala aspek-aspek yang berkaitan dengan terlaksananya kegiatan pembelajaran di sekolah seperti pembagian tugas, pemberian petunjuk teknis terhadap penyelsaian masalah ataupun pengelolaan keuangan yang efisien dan transparan. Kepala sekolah juga dituntut untuk mampu melakukan pembinaan tenaga kependidikan lainnya, dan pendayagunaan serta pemeliharaan sarana dan prasarana.

Hasil penelitian ini menunjukkan adanya indikasi yang positif kepemimpinan kepala sekolah karena sebagian besar guru memberi penilaian yang positif tentang kualitas kepemimpinan kepala sekolah SD Negeri 2 Kendari. Penilaian yang positif dari para guru tersebut dapat menjadi cerminan bahwa kepala sekolah telah berhasil menjadi pemimpin yang baik bagi para guru SD Negeri 2 Kendari sehingga mampu mengantarkan sekolah yang dipimpinannya menuju tujuan utama dari pendidikan, yaitu menciptakan sumberdaya manusia yang berkualitas. Temuan penelitian ini sejalan dengan pendapat yang dikemukakan oleh Istianto dalam Satriadi (2016, p. 132) bahwa sebuah organisasi, kesuksesan atau kegagalan dalam pelaksanaan tugas dan penyelenggaraan, dipengaruhi oleh kepemimpinan, melalui kepemimpinan dan didukung oleh kapasitas organisasi yang memadai, maka penyelenggaraan tata pemerintahan yang baik (Good Governance) akan terwujud, sebaliknya kelemahan kepemimpinan merupakan salah satu sebab keruntuhan kinerja birokrasi di Indonesia. 


\section{Kinerja Pedagogik Guru}

Pada institusi pendidikan, peran penting selain diemban oleh kepala sekolah juga dipegang oleh seorang guru. Jika kepala sekolah lebih berfungsi dalam hal manajerial, peran guru lebih mendominasi tentang aspek pembelajaran. Kinerja guru secara garis besar adalah aktivitas guru yang dilakukan dalam rangka membimbing, mendidik, mengajar, dan melakukan transfer knowledge kepada anak didik sesuai dengan kemapuan keprofesionalan yang dimilikinya dan hasil atau taraf kesuksesan yang dicapai oleh pimpinan lembaga pendidikan terutama kepala sekolah. Rachmawati (2013, p. 20) menyatakan kinerja dalam konteks profesi guru adalah kegiatan yang meliputi perencanaan pembelajaran, pelaksanaan pembelajaran/KBM, dan melakukan penilaian hasil belajar.

Kinerja guru yang akan dibahas pada pembahasan ini adalah kinerja guru pada aspek pedagogik, terdapat tujuh indikator yang harus dikuasai oleh guru pada aspek pedagogiknya yaitu mengenal karakteristik peserta didik, menguasai teori belajar dan prinsip-prinsip pembelajaran yang mendidik, pengembangan kurikulum, kegiatan pembelajaran yang mendidik. memahami dan mengembangkan potensi, komunikasi dengan peserta didik, serta penilaian dan evaluasi.

Berdasarkan hasil penelitian diketahui bahwa dari 31 orang guru di SD Negeri 2 Kendari yang menjadi responden dalam penelitian ini, sebagian besar diantaranya yaitu sebanyak 23 orang atau sekitar 74\% guru memiliki kinerja pada kategori tinggi. Sedangkan 8 orang guru lainnya atau sekitar $26 \%$ memiliki kinerja pada kategori sedang. Berdasarkan hasil tersebut dapat diintepretasikan bahwa kinerja guru cukup baik. Hasil penelitian menunjukkan suatu indikasi yang positif, yaitu memberi gambaran mengenai kinerja guruguru di SD Negeri 2 Kendari sebagian besar mempunyai kinerja pedagogik yang tinggi. Temuan ini sejalan dengan pendapat Enuemel dan Egwunyenga dalam Nasrun (2016, p. 69) yang menyimpulkan bahwa kepala sekolah yang menjalankan perannya dengan memberikan instruksi yang jelas kepada guru akan mempengaruhi kinerja guru. Gaya kepemimpinan yang efektif serta dapat memotivasi guru akan mampu menjadi dasar dan pondasi untuk meningkatkan kinerja guru yang akan berdampak pada peningkatan organisasi

\section{Pengaruh kepemimpinan kepala sekolah terhadap kinerja pedagogik guru di SDN 2 Kendari}

Berdasarkan hasil penelitian, maka hipotesis yang diterima pada penelitian ini adalah persepsi guru mengenai kepemimpinan kepala sekolah berpengaruh positif terhadap kinerja pedagogik guru di SD Negeri 2 Kendari. Hal ini ditunjukkan dengan nilai signifikansi pada uji regresi yang lebih kecil dari taraf signifikansi, yaitu 0,05. Hasil penelitian yang menunjukkan bahwa kepemimpinan kepala sekolah berdasarkan persepsi guru berpengaruh positif terhadap kinerja pedagogik guru di SD Negeri 2 Kendari yang dibuktikan secara statistik. Berdasarkan hasil uji statistik dapat disimpulkan bahwa semakin tinggi kualitas kepemimpinan kepala sekolah akan diikuti oleh peningkatan kinerja guru. Kepemimpinan kepala sekolah mempunyai sumbangan efektif terhadap kinerja guru sebesar 0,2927 yang berarti bahwa kepemimpinan kepala sekolah mampu menjelaskan variabel kinerja guru sebesar $29,27 \%$ sedangkan $70,83 \%$ yang lainnya dipengaruhi oleh variabel lain yang tidak termasuk dalam penelitian ini.

Hasil pengujian tersebut dapat dijelaskan bahwa kepemimpinan kepala sekolah berpengaruh positif secara signifikan terhadap kinerja guru. Hal ini relevan dengan apa yang dikemukakan oleh Mulyasa (2013, p. 92) bahwa erat hubunganya antara kepemimpinan kepala sekolah dengan berbagai aspek kehidupan sekolah seperti disiplin sekolah, iklim budaya sekolah, mutu pembelajaran dan menurunnya perilaku nakal peserta 
didik. Selanjutnya, Ramdhani et al. (2012, p. 11) berpendapat bahwa budaya organisasi pada dimensi ini akan mempengaruhi kualitas organisasi.

Peningkatan kinerja pedagogik yang dimiliki oleh guru di SDN 2 Kendari erat kaitannya dengan bagaimana kepala sekolah memaksimalkan fungsinya dengan baik. Kepala sekolah SDN 2 Kendari telah mampu berfungsi sebagai educator dan leader dengan cukup baik. Hal tersebut sejalan dengan pendapat Mulyasa dalam Sulaiman (2014, p. 59-60) bahwa kepala sekolah berperan utama dalam menggerakan organisasi sekolah. Kepala sekolah yang menjalankan tugasnya dengan cukup baik akan berpengaruh terhadap kinerja guru. Kepala sekolah yang mampu melaksanakan peran dan fungsinya dapat meningkatkan kinerja guru dan dapat juga meningkatkan mutu pendidikan. Kepemimpinan kepala sekolah merupakan faktor yang dapat mendorong sekolah untuk mewujudkan tujuan dan sasaran sekolah melalui program-program yang dilaksanakan secara terencana dan bertahap.

Hasil penelitian ini menyatakan bahwa persepsi guru mengenai kepemimpinan kepala sekolah berpengaruh positif terhadap kinerja pedagogik guru di SD Negeri 2 Kendari sesuai dengan hasil penelitian yang dilakukan oleh Satriadi (2016) yang berjudul pengaruh kepemimpinan kepala sekolah terhadap kinerja guru. Hasil penelitian tersebut memperlihatkan bahwa terdapat hubungan/korelasi yang sangat kuat antara variabel kepemimpinan kepala sekolah (x), dengan kinerja guru di smp negeri 7 tanjung pinang sebesar 0,826 atau mempunyai pengaruh langsung sebesar 68,2 \%. hal ini berarti jika kepemimpinan kepala sekolah sudah baik maka kinerja guru pun terlihat baik.

Hasil penelitian lain yang juga menyatakan bahwa kepemimpinan kepala sekolah berpengaruh positif terhadap kinerja guru dilakukan oleh Sulaiman (2014) dengan judul pengaruh kepemimpinan kepala sekolah terhadap kinerja guru mts-asshobariyah. Hasil penelitian tersebut menunjukkan bahwa faktor yang menentukan kinerja guru yang paling dominan adalah kepemimpinan Kepala Sekolah. Sumbangan pengaruh total kepemimpinan kepala sekolah (X) terhadap kinerja guru (Y) sebesar 81\%. Mengandung arti bahwa semakin baik persepsi seorang guru mengenai kepemimpinan kepala sekolah, maka semakin baik pula kinerja pedagogiknya.

Kemudian hasil dari penelitian ini sekaligus juga mendukung pendapat Istianto (2011, p. 151) bahwa sebuah organisasi, kesuksesan atau kegagalan dalam pelaksanaan tugas dan penyelenggaraan, dipengaruhi oleh kepemimpinan, melalui kepemimpinan dan didukung oleh kapasitas organisasi yang memadai, maka penyelenggaraan tata pemerintahan yang baik (Good Governance) akan terwujud, sebaliknya kelemahan kepemimpinan merupakan salah satu sebab keruntuhan kinerja birokrasi di Indonesia.

\section{Kesimpulan}

Berdasarkan hasil penelitian dan pembahasan yang telah dilakukan, maka dapat disimpulkan bahwa persepsi guru mengenai kepemimpinan kepala sekolah pengaruh positif terhadap kinerja pedagogik guru di SD Negeri 2 Kendari, yang ditunjukkan dengan uji regresi dan nilai signifikansi yang $<0,05$. Berdasarkan hasil uji regresi diperoleh nilai $F_{\text {hitung }}>F_{\text {tabel }}$. Nilai $F_{\text {hitung }}$ yang diperoleh adalah 11,975 sedangkan nilai $F_{\text {tabel }}$ adalah 2,38. Nilai signifikansi yang diperoleh berdasarkan uji regresi adalah 0,002. Koefisien $\mathrm{R}^{2}$ sebesar 0,2927 berarti variabel kepemimpinan kepala sekolah mampu menjelaskan variabel kinerja pedagogik guru sebesar 29,27\%. Sementara 70,83\% yang lainnya diperkirakan dipengaruhi oleh variabel lain yang tidak diungkap dalam penelitian ini. 


\section{Daftar Pustaka}

Istianto, H.B., 2011. Manajemen Pemerintahan Dalam Perspektif Pelayan Publik. Jakarta: Mitra Wacana Media.

Nasrun. (2016). Pengaruh Kepemimpinan Kepala Sekolah Terhadap Motivasi dan Kinerja Guru. Jurnal Ilmu Pendidikan. 1(2), 63-70. http://journal2.um.ac.id/index.php/jktpk/article/view/477

Mulyasa, H. E. (2013). Menjadi Kepala Sekolah Profesional. Bandung: Remaja Rosdakarya.

Rachmawati, Y. (2013). Pengaruh Kepemimpinan Kepala Sekolah Terhadap Kinerja Guru. Jurnal Pendidikan Ekonomi IKIP Veteran Semarang, 01(01), 19-28. https://media.neliti.com/media/publications/37067-ID-pengaruh-kepemimpinankepala-sekolah-terhadap-kinerja-guru.pdf.

Ramdhani, M. A., \& Santosa, E. (2012). Key Succes Factors for Organic Farming Development.International Journal of Basic and Applied Science, 1(1), 7-13. https://www.researchgate.net/publication/316349013_Key_Succes_Factors_for Organic_Farming_Development.

Sari, Yulia Purnama. (2015). Kepemimpinan Kepala Sekolah dalam Meningkatkan Kompetensi Profesional Guru di SMA. Manajer Pendidikan. 6(7), 588-596. https://media.neliti.com/media/publications/270886-kepemimpinan-kepalasekolah-dalam-mening-a5c870da.pdf.

Satriadi. (2016). Pengaruh Kepemimpinan Kepala Sekolah Terhadap Kinerja Guru. Jurnal Benefita, 1(3), 123-133. https://www.researchgate.net/publication/318657477_ Pengaruh_Kepemimpinan_Kepala_Sekolah_Terhadap_Kinerja_Guru.

Sugiyono. (2017). Metode Penelitian Kuantitatif, Kualitatif, dan R\&D. Bandung: Alfabeta.

Sulaiman. (2014). Pengaruh Kepemimpinan Kepala Sekolah Terhadap Kinerja Guru MTs-

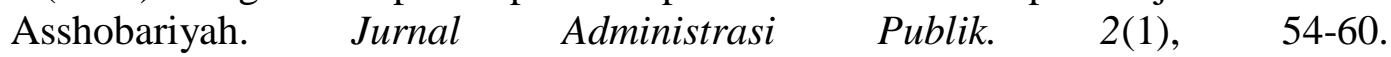
http://ojs.uma.ac.id/index.php/publikauma/article/download/1407/1370.

Syamsul, H. (2017). Penerapan Kepemimpinan Kepala Sekolah dalam Meningkatkan Kinerja Guru Pada Jenjang Sekolah Menengah Pertama (SMP). Jurnal Idaarah, I(2), 275-289. $\quad$ http://journal.uin-alauddin.ac.id/index.php/idaarah/ article/download/4271/3933.

Yudiaatmaja, F. (2013). Kepemimpinan: Konsep, Teori Karakternya. Jurnal Media Komunikasi FIS, 12(2), 29-38. https://ejournal.undiksha.ac.id/index.php/ MKFIS/article/viewFile/1681/1469. 